\title{
Past and Future Changes in Arctic Lake and River Ice
}

\author{
Terry Prowse, Knut Alfredsen, Spyros Beltaos, Barrie Bonsal, \\ Claude Duguay, Atte Korhola, Jim McNamara, Reinhard Pienitz, \\ Warwick F. Vincent, Valery Vuglinsky, Gesa A. Weyhenmeyer
}

\begin{abstract}
Paleolimnological evidence from some Arctic lakes suggests that longer ice-free seasons have been experienced since the beginning of the nineteenth century. It has been inferred from some additional records that many Arctic lakes may have crossed an important ecological threshold as a result of recent warming. In the instrumental record, long-term trends exhibit increasingly later freeze-ups and earlier break-ups, closely corresponding to increasing air temperature trends, but with greater sensitivity at the more temperate latitudes. Broad spatial patterns in these trends are also related to major atmospheric circulation patterns. Future projections of lake ice indicate increasingly later freeze-ups and earlier break-ups, decreasing ice thickness, and changes in cover composition, particularly white-ice. For rivers, projected future decreases in south to north air-temperature gradients suggest that the severity of ice-jam flooding may be reduced but this could be mitigated by changes in the magnitude of spring snowmelt.
\end{abstract}

Keywords Lake ice River ice - Climate change · Paleohydrology $\cdot$ Arctic $\cdot$ Trends

\section{INTRODUCTION}

This manuscript is the second of three papers in this journal special issue (Callaghan et al. 2011) assessing the state and

Electronic supplementary material The online version of this article (doi:10.1007/s13280-011-0216-7) contains supplementary material, which is available to authorized users. fate of freshwater ice in the Arctic. The material originates from the results of an international assessment of arctic lake and river ice conducted by the Arctic Monitoring and Assessment Program, SWIPA project (Snow, Water, Ice, Permafrost in the Arctic) (AMAP 2011). The first introductory manuscript (Prowse et al. 2011a [this issue]) provides details about its overall spatial extent, state of observation programs, and climatic role, while the third reviews the effects of climate-induced changes on ecological, hydrological, and socio-economic systems (Prowse et al. $2011 \mathrm{~b}$ [this issue]).

This manuscript assesses the historical trends in freshwater ice including linkages with climatic controls, followed by recent projected future changes in their phenology and state. To determine the significance of changes in modern properties of lake and river ice, it is useful to place recent observations in a historical context. Unfortunately, long-term monitoring data about the freezing and thawing of Arctic lakes and rivers are scarce. Inferences into past freshwater changes have been made, however, by examining paleolimnological samples that record environmental conditions. These records can provide annual to millennial time series of the composition of lentic biological communities, biogeochemical processes, and changes in lake physical conditions, which can be used for analyses of climate effects on lakes (Battarbee et al. 2005). Detailed analysis of lake sediments can also identify the mechanisms by which climate affects lakes, as well as how climatic variability may interact with other regulatory processes over timescales inaccessible by standard limnological approaches (Leavitt et al. 2009). A detailed review of paleolimnological data about the state and role of ice covers on Arctic lakes is contained in the Supplementary Material. 


\section{TRENDS IN THE INSTRUMENTAL PERIOD}

\section{Trends}

Historical evaluations of changes in freshwater ice conditions over the circumpolar Arctic have proven difficult to synthesize owing to a variety of issues, including the limited number of detailed observations, different observational periods of record, varying in situ observational methodologies and/or phenological definitions, and changes in observation methods, such as from in situ to remote sensing (Prowse et al. 2011a [this issue]). As a result, most trend analyses have focused on relatively simple characteristics that are easy to glean from most agency records, such as the timing of autumn freeze-up and spring break-up, ice-cover duration, and ice thickness. The majority of these analyses have been summarized by Walsh et al. (2005). A detailed review of historical trends in the ice phenology of northern rivers was provided by Beltaos and Prowse (2009).

Long-term records originally analyzed by Magnuson et al. (2000) focused on the period 1846-1995, and included 39 time series of freeze-up or break-up from 26 sites ( 5 rivers, 19 lakes) with records of more than 100 years during this period. Only one site was north of the Arctic Circle, reflecting the lack of high-latitude, long-term observation sites. Overall, 38 of the 39 time series showed either later freeze-up (15 sites averaging +6.3 days 100 year ${ }^{-1}$ ) or earlier break-up (24 sites averaging 5.8 days 100 year $^{-1}$ ), thus resulting in an average reduction in ice duration of 12.1 days 100 year $^{-1}$.

In a subsequent analysis of a smaller set of only northern-hemisphere lakes ( 9 sites for freeze-up and 17 for break-up) for the winters 1855/56-2004/05 from the same database (Koç et al. 2009) (Fig. 1), the rate of change in both events is noted to increase: from +6.3 to +10.7 days 100 year $^{-1}$ for freeze-up and -5.8 to -8.8 days 100 year $^{-1}$ for break-up, thereby further reducing average ice duration by 12.1-17.4 days 100 year $^{-1}$. It is unknown how much of this increased rate of change results from different sample sizes or periods of record. However, some is certainly due to the strong and consistent changes in timing that are evident after the mid-1990s (Fig. 1), which is also the end of the previous period of analysis by Magnuson et al. (2000).

Among most of the shorter-term regional studies, which typically contained far more sites than those used by Magnuson et al. (2000), there is appreciable spatial and interdecadal variability. Much of this is due to analytical differences in the number and location of station data, and the various record lengths used for trend calculations. For example, river-ice trends in North America for the latter half of the twentieth century exhibit a major spatial distinction between western and eastern regions, with the west showing significant and the east, small or insignificant trends toward earlier break-up (Walsh et al. 2005). Similar spatial trends were determined by Duguay et al. (2006) for Canadian lakeice break-up. For Eurasia, Vuglinsky and Gronskaya (2006) found that average freshwater-ice duration decreased between two 20-year periods (1950-1979 and 1980-2000) by $2-10$ days for lakes and rivers in European Russia, and by 3-7 days for rivers and 4-14 days for lakes in Asian parts of Russia. The reductions were attributed to earlier spring break-up and later autumn freeze-up.

Some important south-north contrasts have also been identified in freshwater-ice trends. For example, an investigation of Finnish lakes (with the longest series from the early nineteenth century) showed that, with the exception of the far North, ice-cover duration has become significantly shorter due to later freeze-up and earlier break-up (Korhonen 2006). Similarly, findings from Sweden for the period 1961-1990 revealed a rapid advancement in lake ice break-up of -0.92 day year $^{-1}$ at southern latitudes, whereas the rate was significantly less at only 0.25 day year $^{-1}$ for Arctic lakes (Weyhenmeyer et al. 2005). Contrasting results, albeit involving a more recent period, have been noted for south-north regions of Canada. Based on AVHRR imagery, Latifovic and Pouliot (2007) extended in situ records for 36 Canadian lakes from the 1950s to 2004 and developed new records for six highlatitude lakes from 1985 to 2004. Similar to most of the studies above, the majority of the sites showed earlier break-up (averaging -0.18 day year $^{-1}$ ) and delayed freeze-up (averaging +0.12 day year $^{-1}$ ) dates for the entire period. For the more recent period from 1970-2004, the rates increased to an average of -0.23 and +0.16 day year ${ }^{-1}$, respectively. As noted by Prowse and Brown (2010), however, the most rapid rates of change occurred in the six high-latitude lakes (primarily on the Canadian Archipelago) for the even more recent period of 1985-2004. For these lakes, changes in timing associated with earlier break-up and later freeze-up averaged -0.99 and +0.76 day year ${ }^{-1}$. This translates into an ice-cover reduction rate of 1.75 days year ${ }^{-1}$, or about 4.5 times that found for the more southern parts of Canada for the most rapid depletion period of 1970-2004. The degree to which this reflects the effects of either more recent warming or greater higher-latitude warming or a combination of both is unclear. Explaining the reasons for any of the regional contrasts will require further investigation into factors such as regional differences in controlling heat fluxes, as well as differences that may arise from the use of different observational methods (e.g., in situ vs. remote sensing).

Large-scale, comprehensive records of river- and lakeice thickness are rare. One dataset compiled for Canada over the past 50 years (Lenormand et al. 2002) does not reveal any obvious trends over the latter part of the 
Fig. 1 Long-term records of mean: a freeze-up, b break-up and $\mathbf{c}$ ice-cover duration for northern-hemisphere lakes. The plots present a 2007 update by B.J. Benson and J.J. Magnuson (Koç et al. 2009) of data originally presented by Magnuson et al. (2000)
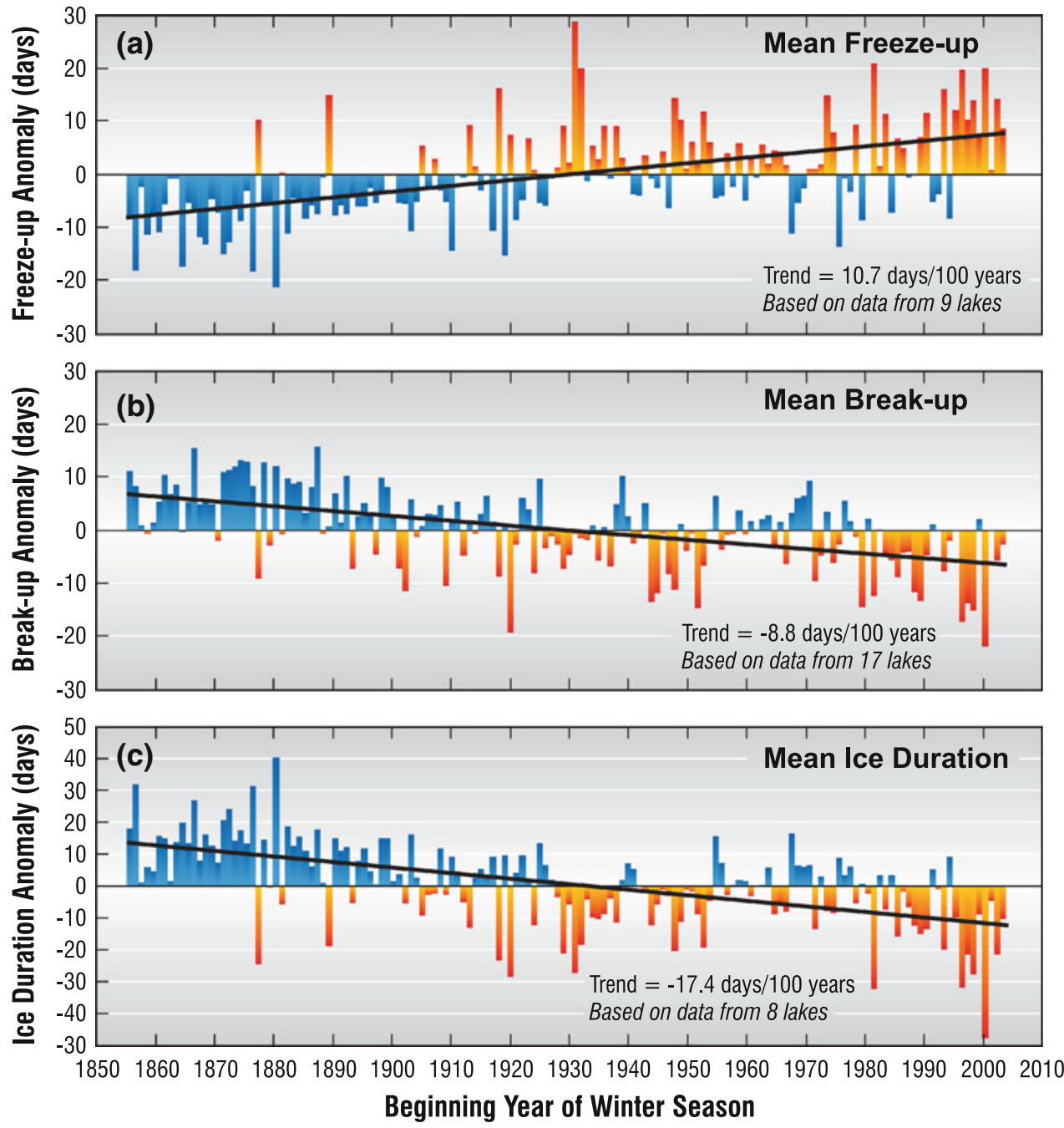

twentieth century (Lemke et al. 2007). However, reductions in maximum ice thickness of $2-14 \mathrm{~cm}$ have been observed on nearly all rivers and lakes within Arctic Russia over the past two decades compared with the previous 30-year period (Vuglinsky and Gronskaya 2006). The largest decreases were found in rivers within Siberia $(\mathrm{Ob}$ : 5-10 cm; Yenisey: 6-14 cm; lower Lena: 11-15 cm).

\section{Linkage of Trends to Climatic Factors}

Freshwater ice duration, thickness, and composition are influenced by a diverse set of hydraulic and hydroclimatic variables that often span the entire ice season. Given this complexity, establishing relationships between freshwater ice trends and climate has generally been conducted simply using air temperature. Ice thickness is the variable most frequently linked to such a readily available, single climatic variable. For example, Vuglinsky and Gronskaya (2006) established a relationship between maximum river- ice thickness and winter air temperature in European Russia. Air temperature, however, has also been used to explain the more complex phenological timing of freeze-up and break-up. Statistically, air temperature during the preceding autumn and spring months is often able to explain $60-70 \%$ of the variance in the timing of ice breakAs noted by Prowse and Bonsal (2004), a first approximation of river-ice response to climatic change based on the analyses of various cold regions indicates that a longterm mean increase of $2-3^{\circ} \mathrm{C}$ in autumn and spring air temperature has produced an approximate 10-day delay in freeze-up and a 15-day advance in break-up. This concurs with the typical 5 days ${ }^{\circ} \mathrm{C}^{-1}$ rate of change in phenological data for many lakes and a few rivers around the Northern Hemisphere (Magnuson et al. 2000). As a result, trends toward shorter freshwater-ice duration over much of the circumpolar North closely correspond to the increasing air temperature trends observed over most of this region. up and freeze-up on lakes and rivers (Walsh et al. 2005). 
Another approach to assessing climatic linkages to freshwater-ice break-up and freeze-up timing has involved relating these events to $0^{\circ} \mathrm{C}$ isotherm dates as defined by Bonsal and Prowse (2003). This variable has the advantage of not being constrained by the traditional seasonal definitions of temperature normally used in large-scale climatic studies. For several rivers within Canada, Lacroix et al. (2005) determined that break-up dates were highly correlated to the timing of spring $0^{\circ} \mathrm{C}$ isotherms over most of the country; however, these relationships were much weaker and less spatially coherent during autumn. In terms of Canadian lakes, similar spatial and temporal patterns have been found between trends (1966-1995) in autumn and spring $0^{\circ} \mathrm{C}$ isotherms and lake freeze-up and break-up dates. In general, this included significant trends toward earlier springs and earlier break-up dates over most of western Canada, and little change in the onset of lower temperatures and freeze-up dates over the majority of the country in autumn (Duguay et al. 2006).

Since air temperature varies sinusoidally over the year, the calendar dates on which the smoothed air temperature falls below $0^{\circ} \mathrm{C}$ (in autumn) and rises above $0^{\circ} \mathrm{C}$ (in spring) are arc cosine functions of the smoothed air temperature, and the fraction of the year during which the ambient air temperature is below $0^{\circ} \mathrm{C}$ can be estimated by $(1 / \pi)$ arc$\cos \left(T_{\mathrm{m}} / T_{\mathrm{a}}\right)$, where $T_{\mathrm{m}}$ and $T_{\mathrm{a}}$ are the mean and amplitude of the annual air temperature cycle (Weyhenmeyer et al. 2005; Livingstone et al. 2010). This arc cosine approach has been validated for more than 40 years of historical ice phenology data from 196 lakes spanning $13^{\circ}$ of latitude in Sweden. Due to the form of this function, the timing of ice break-up (and freeze-up) tends to be more sensitive to variations in air temperature at lower latitudes where mean annual air temperatures are higher, than at higher latitudes where mean annual air temperatures are lower. In other words, the timing of lake-ice break-up appears to respond to changes in air temperature in a non-linear fashion dependent on latitude (Weyhenmeyer et al. 2004, 2005).

\section{Linkage of Trends to Atmospheric Circulation Patterns}

Although freshwater ice-cover duration over the circumpolar North has, for the most part, significantly decreased in response to increasingly warmer conditions during the twentieth century, the patterns have varied regionally, primarily due to climate impacts associated with largescale atmospheric and oceanic oscillations. Teleconnection patterns originating over the Pacific and Atlantic Oceans account for a substantial amount of the observed twentieth century northern-hemisphere temperature trends and variability, especially during winter and spring (Hurrell 1996; Serreze et al. 2000). For example, the El Niño-La Niña/
Southern Oscillation (ENSO), Pacific North American (PNA) pattern, and Pacific Decadal Oscillation (PDO) are closely linked to winter and early spring temperature variability over much of North America, particularly in the west. This includes higher temperatures associated with El Niño events and positive phases of the PNA and PDO, which are all representative of a deepened Aleutian Low (and vice versa) (e.g., Wallace et al. 1995; Bonsal et al. 2001). The most notable pattern in the Pacific involved a shift toward a deeper Aleutian Low after 1976 that has been associated with the trend toward higher winter and spring temperatures over western North America (e.g., Trenberth 1990). The deeper low and associated cyclonic surface circulation allow for more frequent incursions of warm Pacific air into northwestern North America and thus shorter ice durations (especially, earlier break-ups) in this region (Fig. 2). In fact, several studies have demonstrated convincingly that ENSO, the PNA, and the PDO have had significant impacts on the ice phenology of Arctic lakes and rivers within North America including the mid-1970s interdecadal shift (e.g., Benson et al. 2000; Robertson et al. 2000; Bonsal et al. 2006; Blenckner et al. 2007).

In Europe, parts of northern Asia, and northeastern North America, the North Atlantic Oscillation (NAO) (or the Arctic Oscillation (AO) with which it is strongly associated) is known to influence large-scale climate, especially air temperature, in winter and spring (e.g., Hurrell 1995). In particular, a positive NAO (representative of a deepened Icelandic Low in the North Atlantic) is associated with higher temperatures over Europe and northern Asia and lower than normal values over northeastern Canada (and vice versa) (Hurrell 1996). The intensified counter-clockwise circulation of the Icelandic Low results in cold northerly air advection into eastern Canada and greater frequencies of warm maritime flow into Europe and northern Asia (Fig. 2). As a result, a strong winter NAO/AO signal has been detected in the ice phenology of lakes and rivers in Estonia, Finland, Sweden, and northwestern Russia (Livingstone 2000; Yoo and D'Odorico 2002; Blenckner et al. 2007; Karetnikov and Naumenko 2008), and for Lake Baikal in Siberia (Livingstone 1999; Todd and Mackay 2003). These oscillations have also been shown to impact freshwater-ice duration in northeastern Canada (Bonsal et al. 2006). A higher occurrence of positive NAO and AO in the later decades of the twentieth century is consistent with the winter and spring cooling observed over most of northeastern North America and warming in Europe and northern Asia. This, along with the Aleutian Low shift in 1976, helps explain the west to east gradient in air temperature and associated freshwater-ice duration observed over Arctic regions of North America during the latter 50 years of the twentieth century. It is also consistent with the observed trends 


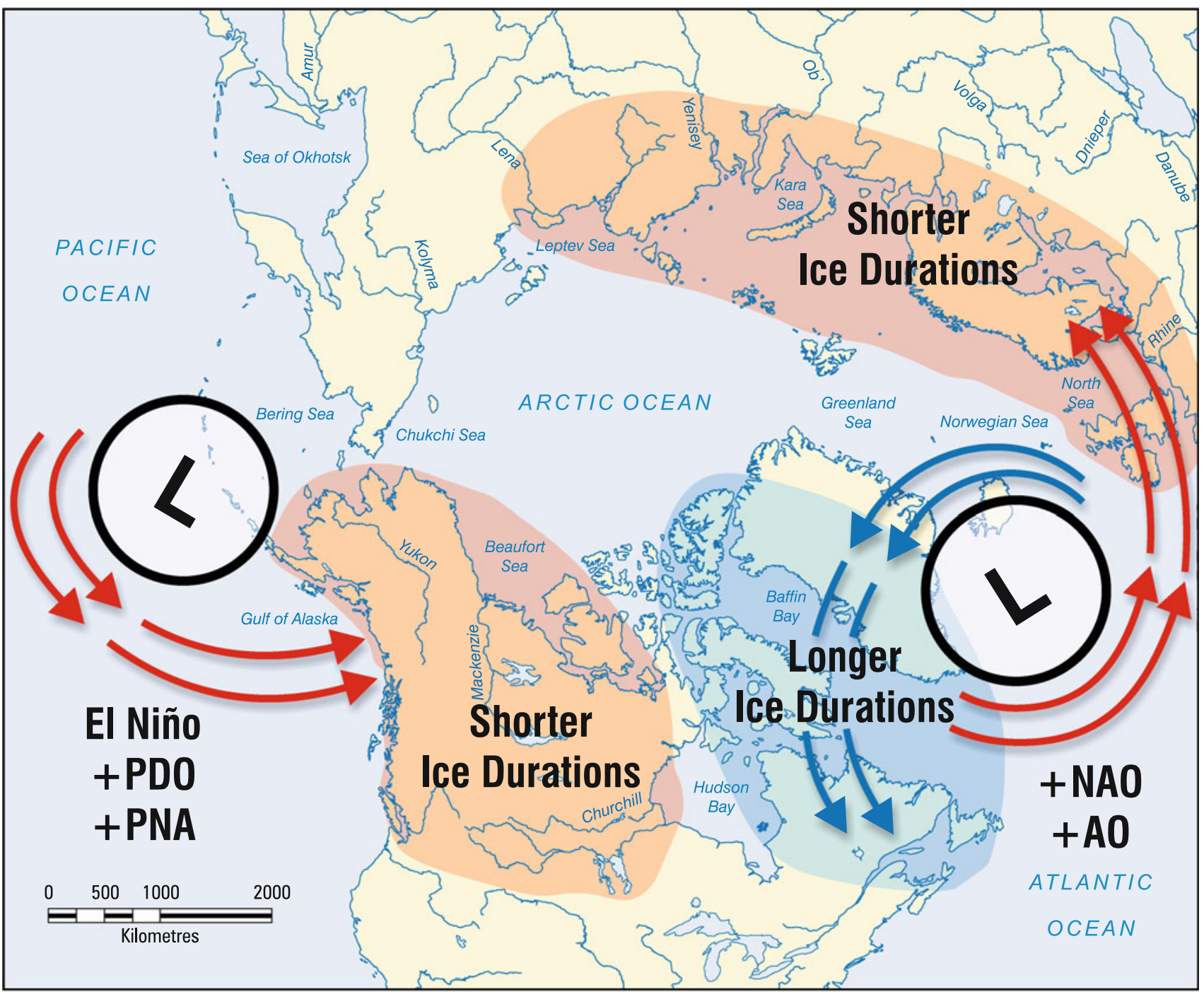

Fig. 2 Schematic illustration showing typical cold-season atmospheric circulation patterns associated with El Niño-La Niña/Southern Oscillation (ENSO), the Pacific Decadal Oscillation (PDO), the Pacific North American (PNA), and the North Atlantic Oscillation/ Arctic
Oscillation (NAO/AO). Positive phases of ENSO (El Nino), the PDO, the (PNA), and the NAO/AO are shown here. Negative phases of these oscillations are associated with opposite temperature changes and freshwater ice durations than shown here toward shorter ice duration in much of Scandinavia and western Russia. Notably, from around 2000 to the present, persistent warm temperature anomalies have occurred in two localized areas, including eastern Siberia and northeastern Canada and Baffin Bay, which is in contrast to temperatures observed during the latter part of the twentieth century. This is the result of a northward displacement and strengthening of the Aleutian Low and a weakening of the Icelandic Low, the latter being reflective of a trend toward more negative $\mathrm{NAO}$ and $\mathrm{AO}$ values since the turn of the century (Overland and Wang 2005). Although not specifically analyzed, it is likely that these two regions have been associated with shorter freshwater-ice duration during this period.

\section{PROJECTED CHANGES}

Similar to the assessment of historical trends in freshwaterice characteristics, the quantification of future changes to lake and river ice is primarily based on degree-day methodologies as inferred by projected temperature changes from climate models. Results from these studies show a continued reduction in freshwater-ice duration (of varying degrees) in all Northern regions. For example, over European Russia and western Siberia, Borshch et al. (2001) applied a uniform warming of $2^{\circ} \mathrm{C}$ to assess changes in river-ice duration. It was determined that break-up would be advanced by 4-10 days and freeze-up delayed by 4-12 days, with the greatest changes in western regions of 
Russia. Relying on the 5 days ${ }^{\circ} \mathrm{C}^{-1}$ rate of change in phenological break-up dates estimated by Magnuson et al. (2000), Prowse et al. (2002) approximated that a projected increase in spring air temperature of $3-7^{\circ} \mathrm{C}$ by the end of this century (as determined from several Global Climate Models (GCMs) would result in a 15- to 35-day advance in river-ice break-up in northern regions of Canada. A more detailed analysis (Prowse et al. 2007) based on average monthly temperature change projections (relative to 1961-1990 using the IPCC A2 emissions scenario from seven GCMs) for the 30-year period centered on the 2050s (2040-2069), found that spring $0^{\circ} \mathrm{C}$ isotherm dates will occur 6-10 days earlier over northern regions of Canada. Autumn changes were even more pronounced ( $\sim 10-12$ days later). Given the aforementioned close correspondence between $0^{\circ} \mathrm{C}$ isotherm dates and freshwater-ice, break-up and freeze-up dates during the instrumental record, the authors hypothesized that by the middle of the 21 st century freshwater-ice duration over much of northern Canada will be about 20 days shorter than during the 1961-1990 baseline period. As noted by Bonsal and Prowse (2003), however, these empirical relationships between freshwater-ice dates and air-temperature indices may not be reliable under future climatic conditions due to changes in the composition of major heat fluxes on which the temperature relationships are founded.

There have only been a few preliminary analyses that have modeled changes in future freshwater-ice phenologies using climate output from GCMs. In the case of lakes, Dibike et al. (2011) incorporated a one-dimensional lake simulation model (MyLake) and atmospheric forcing data from the ERA-40 global re-analysis dataset (Uppala et al. 2005) to simulate lake-ice phenology and ice-type composition for all land masses in a $40^{\circ}$ to $75^{\circ}$ latitudinal band with hypothetical lakes positioned at a resolution of $2.5^{\circ}$ latitude and longitude. Differences in driving climatic variables between a current (1960-1999) and future (2040-2079) run of the Canadian GCM (CGCM3) were applied to the current data to project future ice conditions. Results indicated that future warming will result in an overall increase in lake-water temperature, with summer stratification starting earlier and extending later into the year and, hence, the timing of freeze-up being delayed by 5-20 days (Fig. 3). Break-up was projected to occur 10-30 days earlier, resulting in an overall decrease in lakeice duration of about 15-50 days. Maximum lake-ice thickness was also modeled to decrease by $10-50 \mathrm{~cm}$. In general, maximum snow depth changed by -20 to $+10 \mathrm{~cm}$ and white ice by -20 to $+5 \mathrm{~cm}$, depending on the geographical location and other climate parameters - the high latitudes being an area of projected increases in winter snowfall that can promote white-ice formation particularly with thinner ice cover.

There are fewer projections of future climate change impacts on river ice. One large-river example is provided by Andrishak and Hicks (2008), who applied a onedimensional hydrodynamic model to assess climate change impacts on ice-cover extent and duration on the Peace River in Canada. Incorporation of air-temperature projections (for the 2050s using the IPCC A2 emissions scenario) from the second generation Canadian GCM resulted in an average reduction in ice duration of 28 days (13 days later for freeze-up and 15 days earlier for break-up).

Much less is known about changes in more complex variables such as ice composition and, in the case of rivers, the frequency and severity of ice jams. One of the more important potential changes to river ice relates to the severity of break-up advance (see also Prowse et al. 2011b). Whether temporal shifts in river-ice duration will produce more or less severe break-up events (i.e., floods) remains unknown, largely because of the complicating role of precipitation, which has the potential both to control the driving (snowmelt runoff) and resisting (ice thickness, strength, composition) forces that affect break-up severity. Although limited, site-specific predictions of change in these two cryospheric components (snow and river ice) have been made to estimate the effect on river-ice break-up severity (Beltaos et al. 2006), broad-scale analyses have not been undertaken.

Figure 4 illustrates average projected changes in $0^{\circ} \mathrm{C}$ conditions on the four largest Arctic rivers based on average values of four GCMs for two future time periods, 2041-2070 and 2071-2100, and referenced to current climate (1979-2008). All four rivers exhibit progressively earlier timing of the $0^{\circ} \mathrm{C}$ isotherm over their entire length. They also show a tendency to greater warming in a downstream (primarily south to north) direction, with the greatest change being for the Lena River. Such a reduction in the current climatic gradient is likely to lead to a more thermal type of break-up (see Prowse et al. 2011a for a description of break-up dynamics) characterized by reduced ice action and ice-jam flooding. This would have major ecological implications for riparian ecosystems, such as river deltas (see Prowse et al. 2011b [this issue]).

Predicting more accurately the state and fate of freshwater ice over the next century will require a number of significant advances, the most difficult being for river ice. For the simpler case of lake ice, improvements will need to be made in the physical modeling of the full-season thermal regime. This is especially important in determining the timing of freeze-up and in considering the increasing role of precipitation (e.g., snow accumulation) that affects icegrowth rates, ice-cover composition, ablation rates, and the 


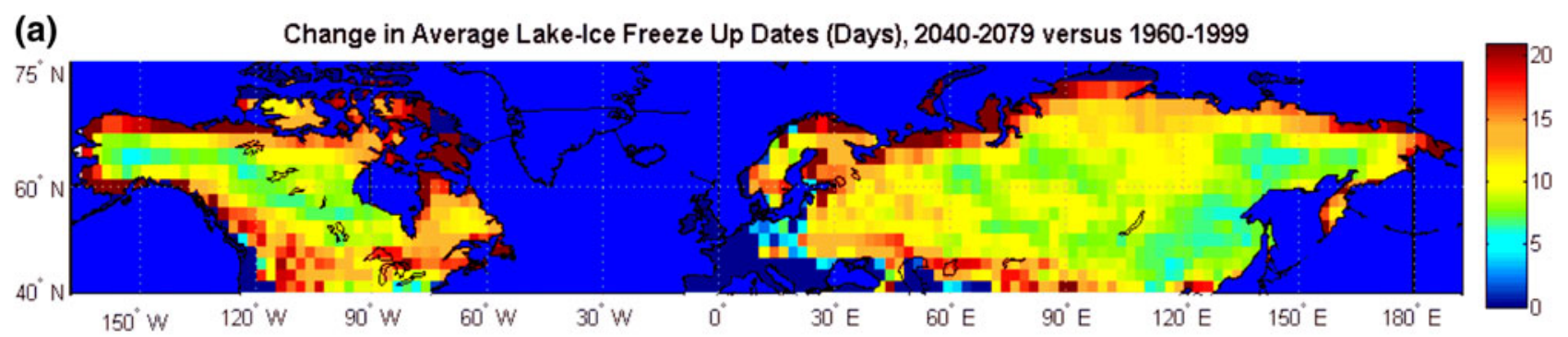

(b)

Change in Average Lake-Ice Break Up Dates (Days), 2040-2079 versus 1960-1999

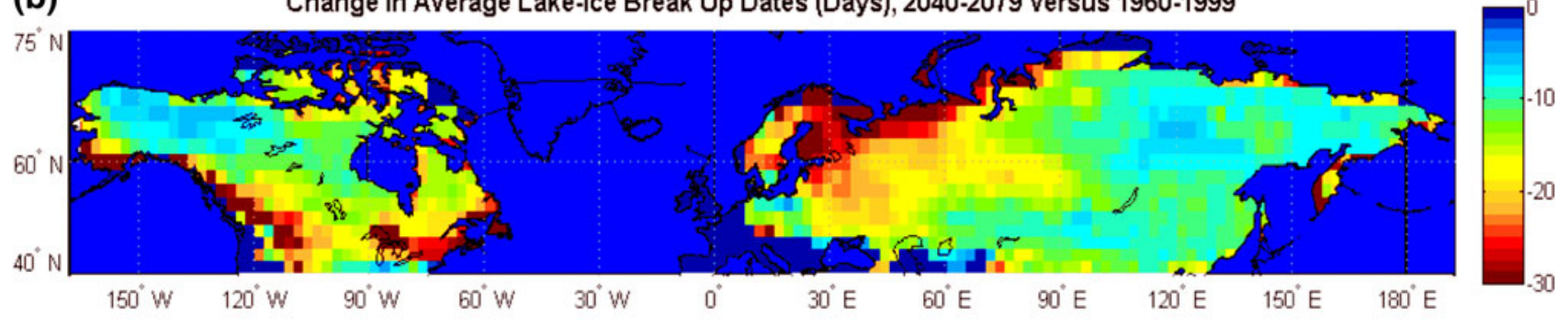

(c) Change in Average Lake-Ice Cover Duration (Days), 2040-2079 versus 1960-1999

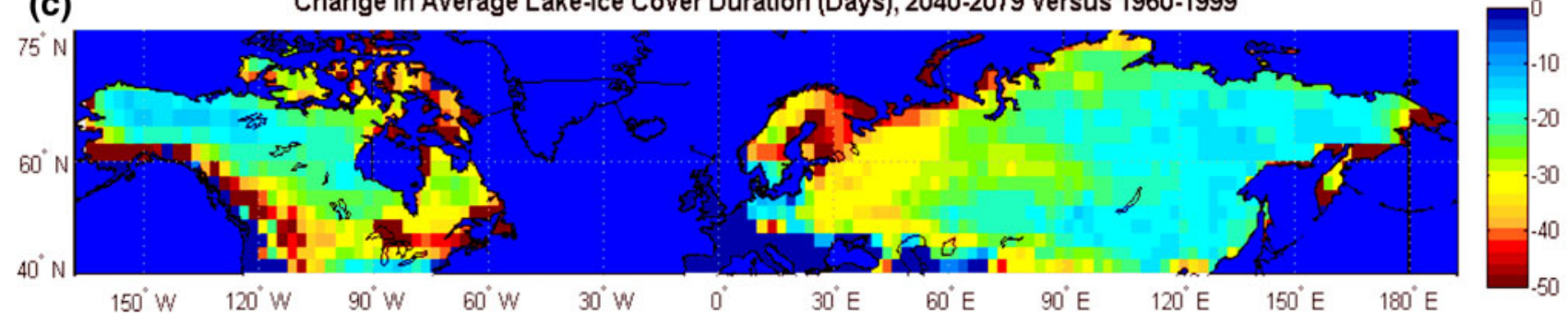

Fig. 3 Change in simulated mean dates of a freeze-up, b ice break-up, and c ice-cover duration between current (1960-1999) and future (2040-2079) climatic periods. Source Dibike et al. (2011)

timing of break-up. As for most other surface variables, refinements will be made to properly downscale (statistically or dynamically) the requisite variables that control surface energy exchanges, including atmospheric coupling to account for feedback in the case of large lakes. Sitespecific to broad-scale predictions of change in most lakeice characteristics would be possible with the advancements noted above (Prowse et al. 2008).

\section{CONCLUSIONS}

Remote Arctic lakes have high potential as natural monitors and recorders of past variation in ice cover because their biological activity is closely coupled to the physical properties of stratification and ice cover, and their fossil record has been little disturbed by human activities. Some records indicate that Arctic lakes may have crossed an important ecological threshold as result of recent warming, which has produced longer open-water periods since the start of the nineteenth century. However, since most paleoanalyses have been conducted on ponds and relatively shallow lakes, the data must be used circumspectly to infer changes on larger lake systems. Closely mirroring the temporal trends and spatial patterns of air temperature, particularly that of the $0^{\circ} \mathrm{C}$-isotherm, observational freshwater-ice records reveal significant trends of later freezeups and earlier break-ups. Although some data indicate greater temperature sensitivity at more temperate latitudes, recent remote-sensing observations of greater change occurring at very high latitudes indicates that further examination of spatial changes in ice cover relative to those for air temperature and controlling atmospheric circulation patterns is required. Projections of future lake-ice conditions indicate further reductions in ice duration associated with increasingly later freeze-ups and earlier break-ups. Ice thickness is also projected to decline but, in areas of enhanced snowfall, greater white ice will develop. Although only limited modeling of river-ice conditions has been conducted, future decreases in south to north air- 

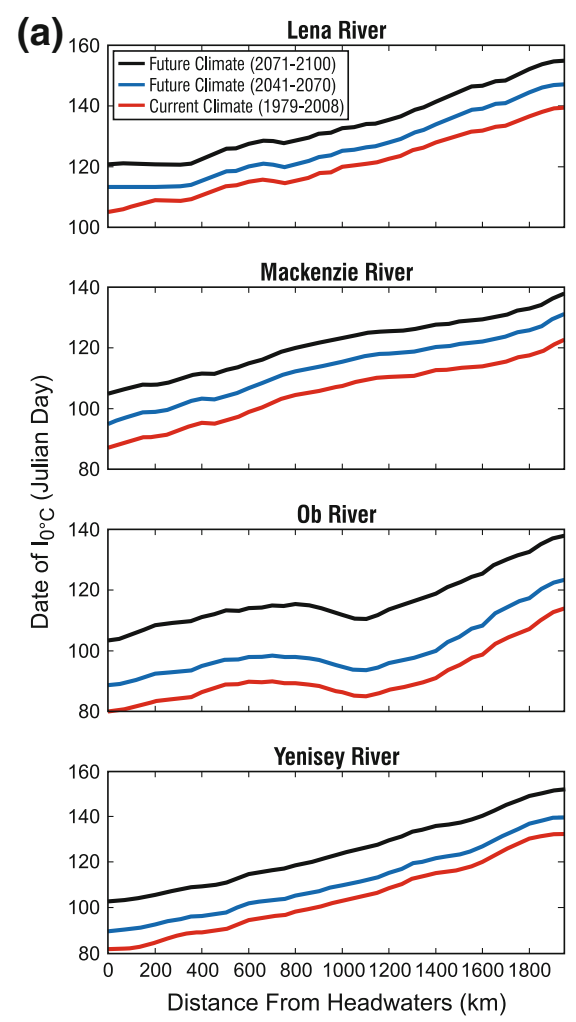

(b)
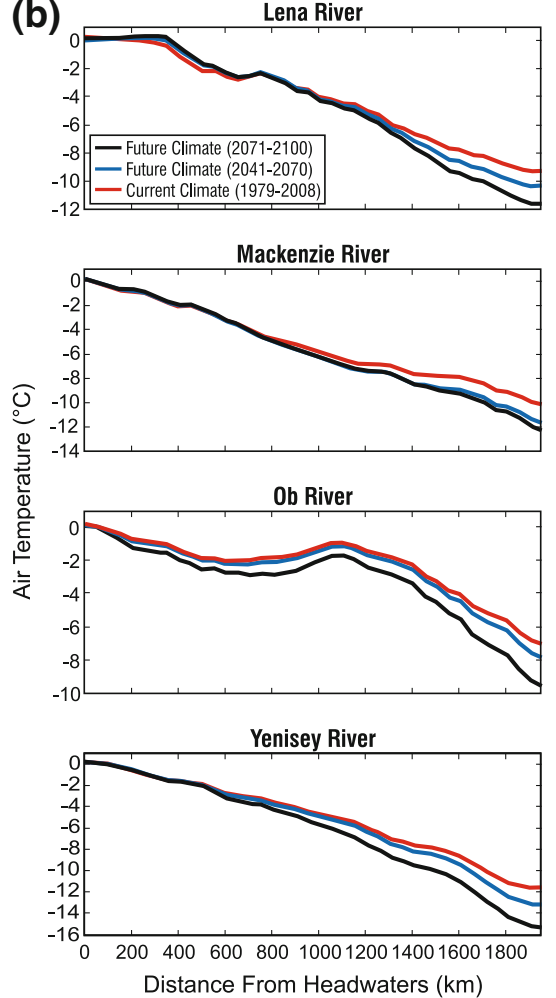
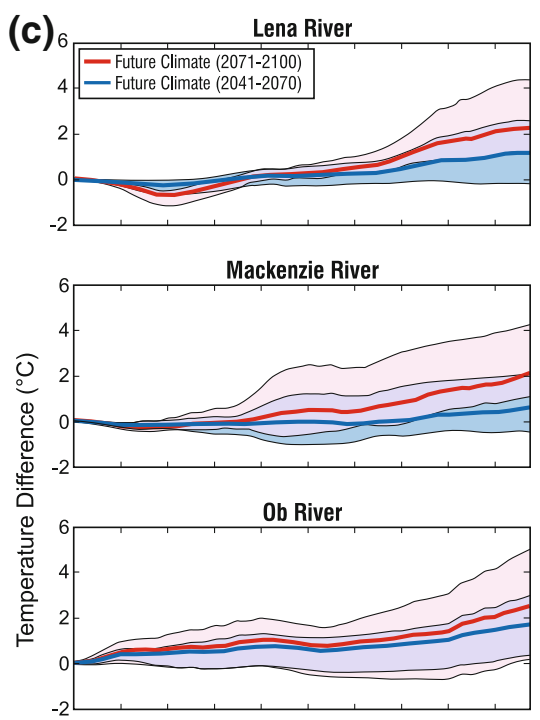

Yenisey River

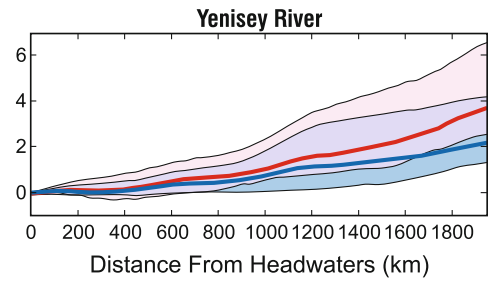

Fig. 4 Projected changes in spring air temperature (average March to May) along the four largest Arctic rivers for two future time periods (2041-2070 and 2071-2100) compared with the current baseline climate (1979-2008): a current and projected $0^{\circ} \mathrm{C}$ isotherm dates along the main-stem reaches of the four large Arctic rivers; $\mathbf{b}$ current

temperature gradients along major northward flowing rivers suggest reductions in the severity of ice-jam flooding.

Acknowledgments The authors wish to thank the various national granting agencies that made this review possible, specifically including the Canadian Natural Sciences and Engineering Research Council, ArcticNet, and Environment Canada who helped directly support this publication. Also gratefully acknowledged are the efforts of the Arctic Monitoring and Assessment Program Secretariat in helping to produce the original SWIPA report and to the various contributing SWIPA chapter authors including B. Bowden, V. Buzin, Y. Dibike, N. Gantner, L. Hinzman, L. Lia, T. Ouarda, J. Reist, M. Stickler, K.M. Walter Anthony, J. Weckström, and F. Wrona.

\section{REFERENCES}

AMAP. 2011. Snow, water, ice and permafrost in the Arctic (SWIPA). Oslo: Arctic Monitoring and Assessment Programme (AMAP). Andrishak, R., and F. Hicks. 2008. Simulating the effects of climate change on the ice regime of the Peace River. Canadian Journal of Civil Engineering 35: 461-472.

Battarbee, R.W., N.J. Anderson, E. Jeppesen, and P.R. Leavitt. 2005. Combining palaeolimnological and limnological approaches in assessing lake ecosystem response to nutrient reduction. Freshwater Biology 50: 1772-1780. and projected air temperature at the time when the upstream sections of the 2000-km main-stem reach $0^{\circ} \mathrm{C}$; and $\mathbf{c}$ associated differences in air temperature between current and future climates. The solid blue and red lines are the GCM-ensemble means, while shading denotes the full range of projected GCM values. Source Prowse et al. (2010)

Beltaos, S., and T. Prowse. 2009. River-ice hydrology in a shrinking cryosphere. Hydrological Processes 23: 122-144.

Beltaos, S., T. Prowse, B. Bonsal, R. MacKay, L. Romolo, A. Pietroniro, and B. Toth. 2006. Climatic effects on ice-jam flooding of the Peace-Athabasca Delta. Hydrological Processes 20: 4031-4050.

Benson, B.J., J.J. Magnuson, R.L. Jacob, and S.L. Fuenger. 2000. Response of lake ice breakup in the northern hemisphere to the 1976 interdecadal shift in the North Pacific. Verhandlungen der Internationalen Vereinigung für Theoretische und Angewandte Limnologie 27: 2770-2774.

Blenckner, T., R. Adrian, D.M. Livingstone, E. Jennings, G.A. Weyhenmeyer, D.G. George, T. Jankowski, M. Järvinen, et al. 2007. Large-scale climatic signatures in lakes across Europe: a meta-analysis. Global Change Biology 13: 1314-1326.

Bonsal, B.R., A. Shabbar, and K. Higuchi. 2001. Impacts of low frequency variability modes on Canadian winter temperature. International Journal of Climatology 21: 95-108.

Bonsal, B.R., and T.D. Prowse. 2003. Trends and variability in spring and autumn $0^{\circ} \mathrm{C}$-isotherm dates over Canada. Climatic Change 57: 341-358.

Bonsal, B.R., T.D. Prowse, C.R. Duguay, and M.P. Lacroix. 2006. Impacts of large-scale teleconnections on freshwater-ice break/ freeze-up dates over Canada. Journal of Hydrology 330: 340353.

Borshch, S.V., B.M. Ginzburg, and I.I. Soldatova. 2001. Modeling the development of ice phenomena in rivers as applied to the assessment of probable changes in ice conditions at various scenarios of the future climate. Water Resources 28: 194-200. 
Callaghan, T.V., M. Johansson, and T.D. Prowse eds. 2011. Arctic cryosphere: Changes and impacts, ed. T.V. Callaghan, M. Johansson, and T.D. Prowse. Ambio 40(S1). doi:10.1007/s13280011-0210-0.

Dibike, Y., T. Prowse, T. Saloranta, and R. Ahmed. 2011. Response of Northern Hemisphere lake-ice cover and lake-water thermal structure patterns to a changing climate. Hydrological Processes. doi: 10.1002/hyp.8068.

Duguay, C.R., T.D. Prowse, B.R. Bonsal, R.D. Brown, M.P. Lacroix, and P. Ménard. 2006. Recent trends in Canadian lake ice cover. Hydrological Processes 20: 781-801.

Hurrell, J.W. 1995. Decadal trends in the North Atlantic Oscillationregional temperatures and precipitation. Science 269: 676-679.

Hurrell, J.W. 1996. Influence of variations in extratropical wintertime teleconnections on Northern Hemisphere temperature. Geophysical Research Letters 23: 665-668.

Karetnikov, S.G., and M.A. Naumenko. 2008. Recent trends in Lake Ladoga ice cover. Hydrobiologia 599: 41-48.

Koç, N., B. Njåstad, R. Armstrong, R.W. Corell, D.D. Jensen, K.R. Leslie, A. Rivera, Y. Tandong, and J.-G. Winther (eds.). 2009. Melting snow and ice: A call for action, 92. Gylling: Narayana Press.

Korhonen, J. 2006. Long-term changes in lake ice cover in Finland. Nordic Hydrology 37: 347-363.

Lacroix, M.P., T.D. Prowse, B.R. Bonsal, C.R. Duguay, and P. Ménard. 2005. River ice trends in Canada. Paper presented at 13th workshop on the hydraulics of ice covered rivers, 41-55. Canadian Geophysical Union, Committee on River Ice Processes and the Environment, September 5-16, in Hanover, NH, USA.

Latifovic, R., and D. Pouliot. 2007. Analysis of climate change impacts on lake ice phenology in Canada using the historical satellite data record. Remote Sensing of Environment 106: 492-507.

Leavitt, P.R., S.C. Fritz, N.J. Anderson, P.A. Baker, T. Blenckner, L. Bunting, J. Catalan, D.J. Conley, et al. 2009. Paleolimnological evidence of the effects on lakes of energy and mass transfer from climate and humans. Limnology and Oceanography 54: 2330-2348.

Lemke, P., J. Ren, R. Alley, I. Allison, J. Carrasco, G. Flato, Y. Fujii, G. Kaser, et al. 2007. Observations: Changes in snow, ice and frozen ground. In: Climate Change 2007: The physical science basis. Contribution of Working Group 1 to the Fourth Assessment Report of the Intergovernmental Panel on Climate Change, ed. S. Solomon, D. Qin, and M. Manning, 337-384. New York: Cambridge University Press.

Lenormand, F., C.R. Duguay, and R. Gauthier. 2002. Development of a historical ice database for the study of climate change in Canada. Hydrological Processes 16: 3707-3722.

Livingstone, D.M. 1999. Ice break-up on southern Lake Baikal and its relationship to local and regional air temperatures in Siberia and to the north Atlantic Oscillation. Limnology and Oceanography 44: $1486-1497$.

Livingstone, D.M. 2000. Large-scale climatic forcing detected in historical observations of lake ice break-up. Verhandlungen der Internationalen Vereinigung für Theoretische und Angewandte Limnologie 27: 2775-2783.

Livingstone, D.M., R. Adrian, T. Blenckner, G. George, and G.A. Weyhenmeyer. 2010. Lake ice phenology. In Impact of climate change on European lakes, ed. G. George, 51-61. Amsterdam: Elsevier Academic Press Inc.

Magnuson, J.J., D.M. Robertson, B.J. Benson, R.H. Wynne, D.M. Livingstone, T. Arai, R.A. Assel, R.G. Barry, et al. 2000. Historical trends in lake and river ice cover in the Northern Hemisphere. Science 289: 1743-1746.

Overland, J.E., and M.Y. Wang. 2005. The third Arctic climate pattern: 1930s and early 2000s. Geophysical Research Letters. 32: 4. doi:10.1029/2005GL024254.
Prowse, T.D., and B.R. Bonsal. 2004. Historical trends in river-ice break-up: a review. Nordic Hydrology 35: 281-293.

Prowse, T.D., and K. Brown. 2010. Hydro-ecological effects of changing Arctic river and lake ice covers: a review. Hydrology Research 41: 454-461.

Prowse, T.D., B.R. Bonsal, and M.P. Lacroix. 2002. Trends in riverice breakup and related temperature controls. Paper presented at Ice in the environment. 16th IAHR international symposium on ice, vol. 3, 64-71, December 2-6, in Dunedin, New Zealand.

Prowse, T.D., B.R. Bonsal, C.R. Duguay, and M.P. Lacroix. 2007. River-ice break-up/freeze-up: A review of climatic drivers, historical trends and future predictions. Annals of Glaciology 26: $443-451$

Prowse, T.D., L. de Rham, and Y. Dibike. 2008. Predicting lake and river ice: Modelling of historical and future conditions. WCRP/ SCAR Climate and Cryosphere Newsletter 10: 8-9.

Prowse, T.D., R. Shrestha, B. Bonsal, and Y. Dibike. 2010. Changing spring air-temperature gradients along large northern rivers: Implications for severity of river-ice floods. Geophysical Research Letters 37:L19706. doi:10.1029/2010GL044878.

Prowse, T.D., K. Alfredsen, S. Beltaos, B.R. Bonsal, C. Duguay, A. Korhola, J. McNamara, W.F. Vincent, et al. 2011a. Arctic freshwater ice and its climatic role. In Arctic cryosphereChanges and impacts, ed. T.V. Callaghan, M. Johansson, and T.D. Prowse. Ambio 40(S1). doi:10.1007/s13280-011-0214-9.

Prowse, T.D., K. Alfredsen, S. Beltaos, B. Bonsal, W.B. Bowden, C. Duguay, A. Korhola, J. McNamara, et al. 2011b. Effects of changes in arctic lake and river ice. In Arctic cryosphereChanges and impacts, ed. T.V. Callaghan, M. Johansson, and T.D. Prowse. Ambio 40(S1). doi:10.1007/s13280-011-0217-6.

Robertson, D.M., R.H. Wynne, and W.Y.B. Chang. 2000. Influence of El Niño on lake and ice cover in the Northern Hemisphere from 1900 to 1995. Verhandlungen der Internationalen Vereinigung für Theoretische und Angewandte Limnologie 27: 2784-2788.

Serreze, M.C., J.E. Walsh, F.S. Chapin III, T. Osterkamp, M. Dyurgerov, V. Romanovsky, W.C. Oechel, J. Morison, et al. 2000. Observational evidence of recent change in the northern high-latitude environment. Climatic Change 46: 159-207.

Todd, M.C., and A.W. Mackay. 2003. Large-scale climatic controls on Lake Baikal ice cover. Journal of Climate 16: 3186-3199.

Trenberth, K.E. 1990. Recent observed interdecadal climate changes in the Northern Hemisphere. Bulletin of the American Meteorological Society 71: 988-993.

Uppala, S.M., P.W. Kållberg, A.J. Simmons, U. Andrae, V.D. Bechtold, M. Fiorino, J.K. Gibson, J. Haseler, et al. 2005. The ERA-40 re-analysis. Quarterly Journal of the Royal Meteorological Society 131: 2961-3012.

Vuglinsky, V.S. and T.P. Gronskaya, 2006. Changing of rivers and lakes ice regime within the Russian territory and their possible consequences for economy. Modern problems of hydrometeorology, 229-245, St. Petersburg, Asterion (in Russian).

Walsh, J.E., O. Anisimov, J.O.M. Hagen, T. Jakobsson, J. Oerlemans, T.D. Prowse, V. Romanovsky, N. Savelieva, et al. 2005. Cryosphere and hydrology. In Arctic climate impact assessment. Scientific report, ed. L. Arris, 183-242. Cambridge: Cambridge University Press.

Wallace, J.M., Y. Zhang, and J.A. Renwick. 1995. Dynamic contribution to hemispheric mean temperature trends. Science 270: 780-783.

Weyhenmeyer, G.A., M. Meili, and D.M. Livingstone. 2004. Nonlinear temperature response of lake ice breakup. Geophysical Research Letters 31. doi:10.1029/2004GL019530.

Weyhenmeyer, G.A., M. Meili, and D.M. Livingstone. 2005. Systematic differences in the trend toward earlier ice-out on Swedish lakes along a latitudinal temperature gradient. Verhandlungen der 
Internationalen Vereinigung für Theoretische und Angewandte Limnologie 29: 257-260.

Yoo, J.C., and P. D'Odorico. 2002. Trends and fluctuations in the dates of ice break-up of lakes and rivers in Northern Europe: The effect of the North Atlantic oscillation. Journal of Hydrology 268: $100-112$.

\section{AUTHOR BIOGRAPHIES}

Terry Prowse $(\square)$ is a senior Research Scientist with Environment Canada and a Professor in the Department of Geography at the University of Victoria. His research focuses on the effects of climate variability and change on cold regions hydrology, hydroclimatology, and hydroecology.

Address: Environment Canada, Department of Geography, University of Victoria, Victoria, BC V8P 5C2, Canada.

e-mail: terry.prowse@ec.gc.ca

Knut Alfredsen is a Professor in Hydrology at the Norwegian University of Science and Technology. His main research interests include river ice, cold climate ecohydrology and environmental impacts of hydropower.

Address: Department of Hydraulic and Environmental Engineering, NTNU, 7491 Trondheim, Norway.

e-mail: knut.alfredsen@ntnu.no

Spyros Beltaos is a Senior Research Scientist at the National Water Research Institute of Environment Canada and an Adjunct Professor at the Department of Geography, University of Victoria. His research interests include hydroclimatic and ecological impacts of ice processes in northern rivers and deltas, with emphasis on breakup and ice jams.

Address: National Water Research Institute, Aquatic Ecosystem Impacts Research Division Environment Canada, 867 Lakeshore Rd, Burlington, ON L7R 4A6, Canada.

e-mail: spyros.beltaos@ec.gc.ca

Barrie Bonsal is a Research Scientist with Environment Canada where he specializes in the assessment of past and projected future climatological impacts on the hydrology and ecology of Canada and the Northern Hemisphere.

Address: National Hydrology Research Centre, Environment Canada, 11 Innovation Blvd, Saskatoon, SK S7N 3H5, Canada.

e-mail: barrie.bonsal@ec.gc.ca

Claude Duguay is a Professor in the Department of Geography \& Environmental Management and Founding Director of the Interdisciplinary Centre on Climate Change at the University of Waterloo. His research interests include climate-lake interactions, remote sensing and numerical modeling of the cryosphere, and northern hydrology.

Address: Department of Geography \& Environmental Management, University of Waterloo, 200 University Avenue West, Waterloo, ON N2L 3G1, Canada.

e-mail: crduguay@uwaterloo.ca

Atte Korhola is a Professor of Environmental Change at the University of Helsinki and a member of the Environment Panel of the European Academies Science Advisory Council (EASAC). His specialist research interests include climate change and its ecological and societal impacts with particular reference to longer term environmental changes and northern regions.

Address: Department of Environmental Sciences, ECRU, University of Helsinki, P.O. Box 65, Viikinkaari 1, 00014 Helsinki, Finland. e-mail: atte.korhola@helsinki.fi

Jim McNamara is a Professor of Hydrology at Boise State University in Boise Idaho, USA. His research interests include interactions between catchment hydrologic, geomorphologic, and biologic processes in cold regions.

Address: 1910 University Dr., Boise State University, Boise, ID 83703, USA.

e-mail: jmcnamar@boisestate.edu

Reinhard Pienitz is a Professor in the Department of Geography and researcher at the Centre for Northern Studies at Universite Laval, Quebec City, Canada. He uses paleolimnological and paleoceanographic approaches involving biological proxy indicators to study the history of climate variability and environmental changes in arctic and subarctic regions.

Address: Dépt de Géographie \& Centre d'Études Nordiques (CEN) Université Laval, Québec City, QC G1K 7P4, Canada. e-mail: reinhard.pienitz@cen.ulaval.ca

Warwick F. Vincent is a Professor of Biology and Canada Research Chair at Laval University, Canada, where he is also director of the Centre for Northern Studies (CEN), an inter-interuniversity centre of excellence for research on northern ecosystems and geosystems. He works on the effects of environmental change on polar aquatic ecosystems.

Address: Département de Biologie \& Centre d'Études Nordiques (CEN), Laval University, Québec City, QC G1V 0A6, Canada.

e-mail: warwick.vincent@bio.ulaval.ca

Valery Vuglinsky is a Professor and Deputy Director for Science at the State Hydrological Institute in the Russian Federation; he is also Head of Hydrology Department at St. Petersburg State University. His main research interests include: water resources and water balance, hydrology of lakes and reservoirs, water resources inventory and hydroecology.

Address: State Hydrological Institute, 2nd Line 23, St. Petersburg 199053, Russian Federation.

e-mail: vvuglins@vv4218.spb.edu

Gesa A. Weyhenmeyer is an Associate Professor and Senior Lecturer at Uppsala University and the Swedish University of Agricultural Sciences. She is presently a Research Fellow Post at the Royal Swedish Academy of Sciences and focuses her research on global change impacts on aquatic ecosystems.

Address: Department of Ecology and Genetics/Limnology, Uppsala University, Norbyvägen 18D, 75236 Uppsala, Sweden.

e-mail: gesa.weyhenmeyer@ebc.uu.se 